\title{
University cuts 'lack real justification'
}

[SYDNEY] Australian universities have appealed to the government to increase rather than cut funding of higher education to avoid the country falling behind its counterparts in South-East Asia - and losing its academic reputation in the process.

The appeal was made against a backdrop of increasing unrest on university campuses. It reflects growing concern about the impact of changes implemented abruptly last year by Amanda Vanstone, education minister in the then newly elected Coalition government of Prime Minister John Howard.

Vanstone has already hinted in a Senate committee hearing that the government may break an undertaking that cuts totalling 5 per cent over the next three years would not be extended beyond that period. Vanstone suggested that there might be a further 1 per cent cut in a fourth year.

At the time of last year's announcement, universities complained bitterly that cuts had been made to operating grants and student fees increased purely for financial reasons, with little justification in terms of policy (see Nature 382, 569; 1996).

After the cuts had been ratified by the
Senate, Vanstone set up early this year the first national review of the role of, demand for and provision of higher education for a decade. The sevenmember review panel is chaired by Roderick West, the highly regarded former headmaster of a private boys' school, and includes three senior university officials.

The panel is due to Gale: warns prestige report by the end of maybe undermined. 1997. Its work coin-

cides with growing uncertainty and unrest in universities and public research institutions. Staff have staged stoppages because of forced redundancies and pay claims, and students have occupied university offices and demonstrated noisily whenever Vanstone has appeared in public.

One of the most contentious changes has been to allow universities that wish to do so to charge full fees to Australian students up to a maximum of 25 per cent of total undergraduates in any course - to make up

\section{Australian funding begins long drift downhill}

[CANBERRA] The second

budget of Australia's Coalition

government, released in

Canberra this week, provides

no new initiatives for

research, and is likely to

generate concern among

scientists about their

prospects in a conservative

political climate.

While the heavy cuts in

last year's budget were

justified in terms of a need to reduce a deficit inherited

from the previous Labor government, Peter Costello, the Treasurer, said on Tuesday (13 May) that more cuts and revenue-raising measures were needed to place the budget in surplus in the financial year that starts on 1 July.

In his speech to

parliament, Costello made no reference to science or technology. Nor did he refer to higher education (see above) or to any other form of intellectual or cultural activity - suggesting that the government does not see these as contributing to the economic recovery it is predicting.

The amount of public funds to be committed to research and development next year show an increase over the current year, expressed in current dollars. But figures adjusted for inflation show a downward trend starting gently in 1997 and accelerating to 2001.

Science and technology minister Peter MoGauran, who is responsible for onefifth of the government's outlays on research spread over seven ministries, said in a statement issued with the budget that the government was "moving ahead with its strategy of making science spending more relevant and accountable".

MoGauran repeated the priority for marine science that was announced last year. But he gave no indication of any new activities in this field - or in any of the government's research agencies.

Last month, MoGauran told the Cooperative Research Centres

Association that their 66 centres, costing $A \$ 142$ million (US\$110 million) this year, are the "centrepiece" of government policy and that he sees them as "catalysts for economic growth" (see Nature 385, 191; 1997). In his budget statement, he argued that the government had "maintained its commitment to the program" and that funding was "fully in place".

But figures in the forward estimates of the budget reveal that funding for the centres will be cut by 5.5 per cent in 1998-99. The association has been told that total funding will be cut by $A \$ 1$ million next year, and by $A \$ 10$ million in the following year.

Health and medical research faces a similar fate. After a small increase next year, forward estimates nosedive by 14 per cent in each of the next two years. Defence research drops this year by 12 per cent. for the loss of income due to government cuts. Until now, only students from overseas have been charged full fees. These are a significant source of income for universities, producing an estimated $\mathrm{A} \$ 600$ million (US\$470 million) in 1996.

The two oldest universities, Sydney and Melbourne, were among the first to announce plans to offer full-fee places, Sydney's ranging from $A \$ 33,000$ for a three-year degree in humanities to $\mathrm{A} \$ 100,000$ for a four-year degree in dentistry.

But some universities, including Australian National University and LaTrobe University, have said that they will rely solely on the present system of partially deferred fees. They argue that they remain committed to a policy of wide access and equity.

Last weekend saw violent student demonstrations in both Melbourne and Sydney over the introduction of full fees for Australians. At Sydney, students broke into the vice-chancellor's office, from which they were evicted by the police.

Staff and students also demonstrated at the University of New South Wales last Friday (9 May) because of a decision by the university's council to award the vice-chancellor a pay rise of $A \$ 50,000$ at a time when the university is considering introducing full fees.

Another recent ruling that has shaken science-based faculties, already concerned about declining enrolments for first degrees, is that postgraduate awards are to be taxed. Last week, an alliance of staff and students vowed to continue its campaign against the many changes until the next election, due in less than two years.

The combined submission to the government on behalf of the country's 37 universities was issued by Fay Gale, president of the Australian Vice-Chancellors' Committee and vice-chancellor of the University of Western Australia. Gale said there was unanimous agreement that spending on higher education - including contributions from industry - should increase from 1.65 to 2 per cent of the country's gross domestic product by 2010 .

Gale pointed out that Taiwan and Singapore now outstrip Australia in proportion of GDP spent on education at all levels by factors of two and three respectively. "In a relatively short time Australia's national influence, prestige and ultimately security could be undermined," she warned.

The vice-chancellors' committee has joined the Federation of Australian Scientific and Technological Societies in attacking the government's decision last year to cut the tax deduction for research in industry to 125 per cent. The vice-chancellors are seeking its restoration to 150 per cent, and the federation to 200 per cent. 